\title{
The Effect of Information Communication Technology (ICT) Infrastructure availability on FDI inflow in D8 Countries
}

\author{
Wangpeizhi ${ }^{1, \mathrm{a}}$, Gul Rukh Bangash ${ }^{2, \mathrm{~b}}$ \\ ${ }^{1}$ Dean \& Professor of School of International Economics and Trade, Shandong University of Finance \& Economics, Jinan, China \\ ${ }^{2} \mathrm{PhD}$ Candidate of School of International Economics and Trade, Shandong University of Finance \& Economics, Jinan, China
}

\begin{abstract}
This This paper analyzes the effect of ICT infrastructure availability on FDI inflow in D8countries (Bangladesh, Indonesia, Iran, Egypt, Nigeria, Malaysia, Pakistan and Turkey). Panel data for the period 19972018 has been used and the analysis has been done using the fix effect model suggested by Hausman specification test. The result shows positive and significant effect between ICT infrastructure and FDI inflows, along with other controlling variables like market size, trade openness, in case of macroeconomic variable that is exchange rate it has negative but significant effect on FDI inflows.
\end{abstract}

\section{Introduction}

In the literature the importance of FDI (Foreign Direct Investment) and its effect on economic growth is well recognized. As one of the key factors, there are many other complementary benefits in promoting economic growth and increasing employment rates, productivity, improving and transferring soft skills and technological innovation capabilities, and access to international market networks. Because of this, there exists a high competition in world market in order to attract these investments, it is important for developing countries to seek such investment as to speed up their development efforts. D8 countries refer to the 8 developing countries, the objective is to improve the developing countries status is world economy, diversify and create new opportunities in trade relation, to rise the living standard and to enhance the participation of these countries in decision making at the international level. As mentioned earlier the importance of FDI inflows and with its other auxilliary benefits can be one of the contributing factor to achieve its objectives.

\subsection{FDI inflows And ICT Infrastructure:}

ICT (Information Communication Technology) Infrastructure is given much consideration when it come to investors decision making, they will not prefer a country with higher labor cost, increase transport cost, communication gap, non availability of natural resources, rigid policies, deficiency in energy resource and non availability of infrastructure. If investor are efficiency seeking or export orientated, they will give consideration to availability of ICT infrastructure.

Foreign investors will mostly prefer that country that offer less cost over high returns. Evidence show that availability and reliability of good ICT infrastructure either decreases search time, related costs or by upsuring in efficiency as well as in productivity.

\subsection{Hypotheses of The Study}

The following hypothesis is to be tested by this study.

H1: There is positive and significant effect of ICT infrastructure availability (individual using internet $\%$ of population, mobile cellular subscriptions per 100 people, fixed telephone subscriptions per 100 people) on FDI inflows in D8 countries.

$\mathrm{H} 2$ : There is negative and significant effect of exchange rate on FDI inflows in D8 countries.

H3: There is positive and significant effect of market size on FDI inflows in D8 countries.

H4: There is positive and significant effect of trade openness on FDI inflows in D8 countries.

\section{EII.LITERATURE REVIEW}

According to Demirhan and Masca.[2] variables like trade openness, market size, economic stability, and better infrastructure have positive influence on FDI. They investigated to find whether investor who are profit oriented go for large economies or growing economies, for this they used different proxies for market size to know whether it has an effect on FDI or not. It was found that the growth of per capita real GDP has an effect on FDI but in case of per capita real GDP it does not have effect on FDI, this means that the investor will prefer developing economies compared to developed economies. While investors are also attracted to a country with better infrastructure as it has a positive and significant effect on FDI inflows.

Kok and Ersoy. [5] focused on 24 countries to find what determinant is best for attracting FDI in developing countries in consideration with globalization. The result

a1483485091@qq.com bgulrukhbangash@yahoo.com 
found that FDI and its determinants have positive and strong influence on the economic development, while the total debt service/inflation and GDP have significant but negative effect on FDI. Other determinants like telephone, gross capital formation, trade, GDP per capita growth have positive influence on FDI. Among these determinants, telephone main link have strong and positive impact on FDI. According to them FDI is the key element that causes the globalization of the economy as well economic development, because of adopting the best practices across different developing countries.

Azam Gani and Basu Sharma. [13] study shows that increase level of ICT leads to an increase in FDI in developed countries.

Roghieh Gholami et al. [14] In case of developing countries there exist a practical evidence of opposite causal relation causing increase in ICT investment and production capacity with increase in FDI inflows.

Kwan Wai ko. [12] shows a strong evidence of discouraging in FDI when there is presence of negative network externalities in developing countries.

ICT enhances the spillover effect that is more opportunity of employment, enhancing skills, knowledge cause by FDI inflows in host countries. A country's ability to utilize and absorb these supplementary benefits of FDI inflows, if it has more sophisticated ICT structure availability.

\section{METHODOLOGY}

For data collection various secondary data sources are used like World Bank (WB), World Development Indicator (WDI). [9], Penn World. D8 countries is used a sample, setting a panel data from year 1997 to 2018 Where data for FDI, market size, trade openness, mobile user and internet user per 100 is taken from WDI and for exchange rate Penn World data source is used.

Table1. Variables, definitions, excepted effect, source

\begin{tabular}{|c|c|c|c|c|}
\hline Varible & $\begin{array}{l}\text { Proxy } \\
\text { used }\end{array}$ & Defination & $\begin{array}{c}\text { Expect } \\
\text { ed } \\
\text { effect }\end{array}$ & $\begin{array}{c}\text { Source of } \\
\text { data } \\
\text { collection }\end{array}$ \\
\hline $\begin{array}{l}\text { Market } \\
\text { size }\end{array}$ & Pop & Total population & + tive & WDI \\
\hline $\begin{array}{c}\text { Trade } \\
\text { openness }\end{array}$ & Trd opn & $\begin{array}{l}\text { Trade percentage of } \\
\text { gdp }\end{array}$ & + tive & WDI \\
\hline $\begin{array}{c}\text { Macro } \\
\text { Economic } \\
\text { stability }\end{array}$ & Offex rate & Offical exchange rate & -tive & $\begin{array}{l}\text { Penn } \\
\text { world }\end{array}$ \\
\hline \multirow{3}{*}{$\begin{array}{c}\text { ICT } \\
\text { Infrastruct } \\
\text { ure }\end{array}$} & $\begin{array}{l}\text { Mobsub } \\
\text { per } 100\end{array}$ & $\begin{array}{c}\text { Mobile cellular } \\
\text { subscriptions (per } \\
100 \text { people) }\end{array}$ & + tive & WDI \\
\hline & $\begin{array}{c}\text { Internetuse } \\
\text { r per } 100\end{array}$ & $\begin{array}{l}\text { Individuals using the } \\
\text { internet ( } \% \text { of } \\
\text { population) }\end{array}$ & + tive & WDI \\
\hline & $\begin{array}{c}\text { Fixed } \\
\text { telsub/100 }\end{array}$ & $\begin{array}{l}\text { Fixed telephone } \\
\text { subscriptions (per } \\
100 \text { people) } \\
\end{array}$ & + tive & WDI \\
\hline $\begin{array}{c}\text { Foreign } \\
\text { direct } \\
\text { investment }\end{array}$ & $\begin{array}{c}\text { FDI } \\
\text { inflows }\end{array}$ & Net FDI inflows & + tive & WDI \\
\hline
\end{tabular}

\section{MODEL SPECIFICATION}

The following model is selected by the guidance of literature, where as in the model the selection of independent variables and the availability of data is confined to the D8 countries from the period of 1997 to 2018.

1stequation

$\mathrm{FDIjt}=\mathrm{f}$ (Exchange rate, Market Size, Trade Openness, ICT Infrastructure) jt

Where the subscript " $\mathrm{j}$ " indicate listed countries that are D8 varying from 1 to 8 and " $t$ " indicate the time period that is from 1997 to 2018 , thus having 178 as total number of observations in the selected sample. $\beta(1 \cdots .4)$ are the coefficients of the variables and show change in the dependent variable due to unit change in independent variables.

Replacing the variables with the appropriate proxies given and $\log$ linearized as taking $\log$ of the variables helps in removing the expected heteroscedasticity, hence equation 1 gives the equation 2

Lnfdijt $=\alpha o+\beta 1 \ln$ Popjt $+\beta 2 \ln$ Tradejt $+\beta$ $3 \ln X$ ratejt $+\beta 4 \ln$ (Fixed tele sub/100 peoplejt, Mobile user per 100peoplejt, Internet user per 100 peoplejt $)+\xi$ jt*.. (II)

Where InFDI $=\log$ of FDI net inflows US $\$$ and is taken as proxy and also as a dependent variable. $\alpha=$ constant. $\beta_{1} \beta_{2} \beta_{3}$ and $\beta=$ parameters used for linking the the dependent variable with independent variables. InPOP $=$ represent market size and showing the total population of a country. InTRAOPN= Trade as a percentage of GDP. InEXR $=$ is the real exchange rate in US \$. InMOBUSER $/ 100=$ Mobile cellular subscriptions (per 100 people).InINTERNTUSER/100 = Internet user (per 100 person). InFixed Tele sub/100 ppl $=$ is Fixed telephone subscriptions (per 100 people) taken as a proxy of ICT infrastructure is the error term.

\section{ESTIMATION TECHNIQUES}

\subsection{Hypotheses of The Study}

Following the work of Shah.[8], The Hausman test for the introduction of each proxy used for infrastructure is applied to analyze the data, the result that is chi2 (5) $=20.31$, Prob $>$ chi2 (0.0011), the value obtain from the test suggests the fixed effect regression for the proxy mobile user per 100 people and internet user per 100 people, while for a proxy Fixed telephone subscriptions (per 100 people), the result shows the value as Prob $>$ chi $2=0.0000$, suggest to use fixed effect regression. 


\subsection{Descriptive statistics}

Table2. Descriptive statistics

\begin{tabular}{|c|c|c|c|c|c|}
\hline \multicolumn{7}{|c|}{ Summary statistics } \\
\hline $\begin{array}{c}\text { Variable } \\
\text { name }\end{array}$ & $\begin{array}{c}\text { No of } \\
\text { Obs }\end{array}$ & $\begin{array}{c}\text { Mean } \\
\text { Value }\end{array}$ & $\begin{array}{c}\text { Standard } \\
\text { Deviation }\end{array}$ & $\begin{array}{c}\text { Mini } \\
\text { Value }\end{array}$ & $\begin{array}{c}\text { Max } \\
\text { Value }\end{array}$ \\
\hline FDI inflows & 176 & 21.60 & 1.39 & 16.99 & 23.87 \\
\hline Mrtsize & 176 & 18.41 & 0.66 & 16.88 & 19.40 \\
\hline Traopn & 176 & 4.065 & 0.49 & 3.37 & 5.40 \\
\hline Off exrate & 176 & 4.47 & 3.01 & 0.14 & 9.61 \\
\hline Mobsub/100 & 176 & 3.21 & 1.62 & 0.01 & 5.11 \\
\hline $\begin{array}{c}\text { Indusingintnet } \\
\% \text { pop }\end{array}$ & 176 & 2.12 & 1.40 & 0.001 & 4.41 \\
\hline $\begin{array}{c}\text { Fixedtelsub } \\
\text { /100 }\end{array}$ & 176 & 1.97 & 1.14 & 0.07 & 3.68 \\
\hline
\end{tabular}

Table3. Correlation

\begin{tabular}{|c|c|c|c|c|c|c|c|c|}
\hline $\begin{array}{c}\text { Variables } \\
\text { Proxy }\end{array}$ & $\begin{array}{c}\text { No of } \\
\text { Obs }\end{array}$ & $\begin{array}{c}\text { FDI } \\
\text { inflows }\end{array}$ & $\begin{array}{c}\text { Off } \\
\text { Ex } \\
\text { rate }\end{array}$ & Pop & $\begin{array}{c}\text { Trde } \\
\text { Opns }\end{array}$ & $\begin{array}{c}\text { Inter } \\
\text { net } \\
/ \mathbf{1 0 0}\end{array}$ & $\begin{array}{c}\text { Mob } \\
\text { user } \\
/ \mathbf{1 0 0}\end{array}$ & $\begin{array}{c}\text { Fixed } \\
\text { telsu } \\
\text { b/100 }\end{array}$ \\
\hline $\begin{array}{c}\text { FDI } \\
\text { inflows }\end{array}$ & 176 & 1.000 & & & & & & \\
\hline Exrate & 176 & -0.14 & 1.000 & & & & & \\
\hline Pop & 176 & -0.11 & 0.53 & 1.00 & & & & \\
\hline $\begin{array}{c}\text { Traopns } \\
\text { Indusingint } \\
\text { net\%pop }\end{array}$ & 176 & 0.37 & -0.24 & -0.72 & 1.000 & & & \\
\hline $\begin{array}{c}\text { Mob } \\
\text { user/100 }\end{array}$ & 176 & 0.67 & -0.08 & -0.10 & 0.30 & 0.83 & 1.000 & \\
\hline $\begin{array}{c}\text { Fixedtelsub } \\
/ 100\end{array}$ & 176 & 0.31 & -0.07 & -0.63 & 0.40 & 0.59 & 0.33 & 1.000 \\
\hline
\end{tabular}

\subsection{Multicollinerity}

VIF (Variance Inflation Factor) is used as indicative statistic, showing the effect of linear association between explanatory variables upon the variance of estimator as measured by the efficient of determination of R2. The result of VIF which is 4.43 are not to be concerned about as the multicollinearity issues as being not highly based value as according to Hill and Adkins. [3] (pages 264) rules that the value of VIF $>10$ is the level of multicollinearity which is not problematic. The most recommended maximum value of VIF is 5 (e.g. Rogerson, 2001). The maximum value 10 of the VIF is also acceptable and recommended by some authors, Kennedy. [15]

Table4. Descriptive statistics

\begin{tabular}{|l|l|l|}
\hline Variable & VIF & $\mathbf{1 / V I F}$ \\
\hline Lnoff exrate & 2.25 & 0.445 \\
\hline Lnmrtsize & 7.03 & 0.142 \\
\hline Lntradeopns & 3.20 & 0.312 \\
\hline Lninternet \% population & 5.80 & 0.172 \\
\hline Lnmob user/100 people & 4.21 & 0.237 \\
\hline Lnfixedtelsub/1oo people & 3.52 & 0.284 \\
\hline
\end{tabular}

\subsection{Heteroscadasticity}

In order to check for the possible heteroscadascity.
Breush-Pagan/CookWeisberg test is carried out, the test accept the null hypothesis of constant variance with result showing the value of chi $2=0.00$, Prob $>\operatorname{chi} 2=0.997$, thus it shows the there is no existence of heteroscadascity.

\section{RESULT AND DISCUSSION}

The table 5 shows the regression analysis, three models are introduced. The three of model (column1, 2 and 3 ) shows the estimation result for fixed effect regression. In each model variable like market size, trade openness, exchange rate are introduced, while for the infrastructure different aspect or alternative are introduced in each model.

By looking at the models 1,2 and 3 variable exchange rate found to have negative effect on FDI inflows while the significance level of $1 \%$ can only be seen in model 3 . A country with instability in exchange rate causes decrease in inward flow of these investments.

For variable market size have positive endowment across all the estimation method but significant only for model 1 and 3 at $10 \%$ and $1 \%$. Market size is one of the important variable, increases in the size of the market size associated in attracting more FDI inflows in a country.

Similarly Trade openness has positive and significant effect at the level of $1 \%$ in all of three models on FDI inflow, it means that country with flexible trade policy will help in attracting FDI, if foreign investors are provided with trade incentives like, reduced trade tariff, reduction in tax concession etc.

In the model 1, 2, and 3 different proxy of ICT infrastructure have been used. Looking in the model 1 internet user per 100 person is used as a proxy for infrastructure, looking at the sign of positive coefficient and having $1 \%$ significant effect on FDI inflows. The fixed effect (within) regression for model 1 is $49 \%$. Many studies reported a positive relation between growth and internet user or internet host and FDI, thus helps in reducing the prices by decreasing cost of $\mathrm{B} 2 \mathrm{~B}, \mathrm{~B} 2 \mathrm{C}$ and $\mathrm{B} 2 \mathrm{G}$, also contributes in the functioning of domestic and export markets Changku Choi [11].

In the model 2, mobile user per 100 population is used as an alternative proxy for ICT infrastructure, it can been seen that the value of coefficient is positive and has significant effect on FDI inflows at level of significance $1 \%$, while the overall fit of the model is $52 \%$. Thus proving that communication channel is one of the important factor for foreign investors in choosing the FDI locations.

For the model 3 fixed telephone line subscribers per 100 people is introduced as a proxy for ICT infrastructure thus found to have a positive and significant effect on FDI inflows, the significance level is at 1 percent, with fit of model 78\%. A good communication channel is important in order to ensure easy communication way between host and home country.

Table5. Descriptive statistics

\begin{tabular}{|l|l|l|c|c|}
\hline \multirow{2}{*}{ Variables } & \multirow{3}{*}{ Fix effect } \\
\cline { 3 - 5 } & \multirow{2}{*}{ Proxy used } & 1 & 2 & 3 \\
\cline { 3 - 5 } & &
\end{tabular}




\begin{tabular}{|c|c|c|c|c|}
\hline Exchange rate & Offi ex rate & $\begin{array}{l}-0.491 \\
(0.457)\end{array}$ & $\begin{array}{l}-0.609 \\
(0.439)\end{array}$ & $\begin{array}{l}-0.626^{*} \\
(0.445)\end{array}$ \\
\hline Market size & Total population & $\begin{array}{l}2.321 * * * \\
(1.309)\end{array}$ & $\begin{array}{l}0.477 \\
(1.355)\end{array}$ & $\begin{array}{l}6.656^{*} \\
(0.936)\end{array}$ \\
\hline Trade openness & $\begin{array}{l}\text { Trade rate (\% of } \\
\text { gdp) }\end{array}$ & $\begin{array}{l}1.7711^{*} \\
(0.458)\end{array}$ & $\begin{array}{l}2.042 * \\
(0.418)\end{array}$ & $\begin{array}{l}2.309^{*} \\
(0.417)\end{array}$ \\
\hline \multirow[t]{3}{*}{$\begin{array}{l}\text { ICT } \\
\text { infrastructure }\end{array}$} & $\begin{array}{l}\text { Individuals using } \\
\text { the internet (\%of } \\
\text { pop) }\end{array}$ & $\begin{array}{l}0.537 * \\
(0.148)\end{array}$ & & \\
\hline & Mobile user/100 & & $\begin{array}{l}0.525 * \\
(0.103)\end{array}$ & \\
\hline & $\begin{array}{l}\text { Fixedtel sub/100 } \\
\text { ppl }\end{array}$ & & & $\begin{array}{l}1.088^{*} \\
(0.227)\end{array}$ \\
\hline \multicolumn{2}{|c|}{ Fixed effect (within) $R^{2}$ value } & 0.490 & 0.525 & 0.78 \\
\hline \multicolumn{2}{|c|}{ No of observations } & 176 & 176 & 176 \\
\hline \multicolumn{5}{|c|}{$\begin{array}{l}\text { The value of standard error is in parenthesis under coefficient while } * \text { show significance } \\
\text { at } 1 \%,{ }^{* *} \text { show significance at } 5 \% \text { and } * * * \text { at } 10 \% \text {. Values are rounded off to three decimal } \\
\text { places. }\end{array}$} \\
\hline
\end{tabular}

\section{CONCLUSION}

It has been found that with escalation in rate of return and by subsidizing the cost of total investment to the foreign investors, Availability and reliability of good information communication infrastructure such as telephone lines, internet and mobile user's, improves the climate for attracting these foreign investment and thus increase the productivity level and attract FDI inflows in these country, ICT can increase FDI inflows and productivity by decreasing the cost of holding inventories through 'justin-time' inventory management thus permitting a direct link between customers and producers. This study finds that ICT infrastructure have positive and significant effect on FDI inflows. Variables that were often known for their ostentation in the literature like market size, trade openness are pervade throughout the study and thus found to positive and significant effect on FDI inflows. While exchange rate has negative and significant effect, it's important to know that the finding is only confined to D8 countries, thus it not can be generalized to other developing countries, however the result can be used as guidance for improving the FDI inflows in one's country.

\section{References}

1. Asteriou, D., \& Hall, S.G., (2007). Multicollinearity: Applied Econometrics.(Revised edn.,pp. 8599).Hampshire, UK: Palgrave Macmillan.

2. Demirhan, E., \&Masca, M. (2008). Determinants of Foreign Direct Investment Flows to Developing Countries: A Cross-Sectional Analysis. Prague Economic Papers, 4, 356-369.

3. Hill R. C. \& Adkins L. C. (2007). Colinearity.In a Companion to Theoretical Econometrics (ed. Baltagi B. H., editor. pp. 256-278). Oxford, UK: Blackwell Publishing.
4. Hausman, J. A. (1978). Specification Test in Econometrics. ECONOMETRICA, Journal of Econometric Society, 46(6), pp. 1251-1271.

5. Kok, R., \& Ersoy, A. B. (2009). Analyses of FDI determinants in developing countries: International Journal of Social Economics, 36(1/2), 105 - 123.

6. Rehman, C.A., \&Ilyas, M., Alam, H.M., Akram, M. (2011). The Impact of Infrastructure on Foreign Direct Investment: The Case of Pakistan. International Journal of Business and Management, 6(5), 268-276.

7. Shah, M. H. (2010). Essays on Foreign Direct Investment in Developing Countries. UK:Department of Economics, University of Leicester.

8. Shah, M.H., (2014). The Significance of Infrastructure for FDI Inflow in Developing Countries. Journal of Life Economics, 1(2), pp. 1-16.

9. WDI (2002): World Development Indicators, World Bank, Washington DC.

10. Pazienza, Pasquale \& Vecchione, Vincenzo (2009). Preliminary Investigation of the Determinants of FDI Distribution in Italy. Journal of Business Economics and Management, 10, 99-107

11. Changkyu Choi (2003). Does the Internet stimulate inward foreign directinvestment? Journal of Policy Modeling, Vol. 25, Issue 4 (June), pp. 319-326.

12. [Kwan Wai Ko (2007). Internet externalities and location of foreign direct investment: A comparison between developed and developing countries, Information Economics and Policy, Vol. 19, Issue 1 (March), pp. 1-23.

13. Azmat Gani and Basu Sharma (2003). The Effects of Information Technology Achievement and Diffusion on Foreign Direct Investment, Perspectives on Global Development and Technology, Vol. 2, No. 2 (June), pp. 161-178. 